\title{
Uncertainty in simulating biomass yield and carbon-water fluxes from grasslands under climate change
}

CONFERENCE PAPER · MARCH 2015

DOI: $10.1017 /$ S2040470014000545

DOWNLOADS

49
VIEWS

81

16 AUTHORS, INCLUDING:

Marco Acutis

University of Milan

139 PUBLICATIONS 878 CITATIONS

SEE PROFILE

Martin Köchy

Thünen Institute

54 PUBLICATIONS 571 CITATIONS

SEE PROFILE

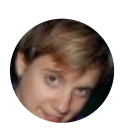

D. Hidy

Szent István University, Godollo

13 PUBLICATIONS 39 CITATIONS

SEE PROFILE

Julien Minet

University of Liège

24 PUBLICATIONS 141 CITATIONS

SEE PROFILE 


\title{
Uncertainty in simulating biomass yield and carbon-water fluxes from grasslands under climate change
}

\author{
R. Sándor ${ }^{1}$, S. Ma ${ }^{1}$, M. Acutis², Z. Barcza ${ }^{3}$, H. Ben Touhami ${ }^{1}$, L. Doro ${ }^{4}$, D. Hidy ${ }^{5}$, M. Köchy ${ }^{6}$, \\ E. Lellei-Kovács ${ }^{7}$, J. Minet ${ }^{8}$, A. Perego ${ }^{2}$, S. Rolinski ${ }^{9}$, F. Ruget ${ }^{10}$, G. Seddaiu ${ }^{4}$, L. Wu $^{11}$ and \\ G. Bellocchi ${ }^{1 \dagger}$
}

${ }^{1}$ French National Institute for Agricultural Research, Grassland Ecosystem Research Unit, 63039 Clermont-Ferrand, France; ${ }^{2}$ Department of Agricultural and Environmental Sciences - Production, University of Milan, Landscape, Agroenergy, 20122 Milan, Italy; ${ }^{3}$ Department of Meteorology, Eötvös Loránd University, 1518 Budapest, Hungary; ${ }^{4}$ Desertification Research Centre, University of Sassari, 07100 Sassari, Italy; ${ }^{5}$ MTA-SZIE Plant Ecology Research Group, Szent István University, 2103 Gödöllö, Hungary; ${ }^{6}$ Thünen Institute of Market Analysis, Braunschweig, 38116 Germany; ${ }^{7}$ MTA Centre for Ecological Research, Institute of Ecology and Botany, 2163 Vácrátót, Hungary; ${ }^{8}$ Arlon Environment Campus, University of Liège, 6700 Arlon, Belgium; ${ }^{9}$ Potsdam Institute for Climate Impact Research, 14473 Potsdam, Germany; ${ }^{10}$ French National Institute for Agricultural Research, Modelling Agricultural and Hydrological Systems in the Mediterranean Environment, 84914 Avignon, France, ${ }^{11}$ Rothamsted Research, North Wyke, EX20 2SB Okehampton, UK

Keywords: grassland productivity, carbon balance, model simulation, uncertainty, sensitivity

\section{Introduction}

Uncertainty in the response of agro-ecosystem models to environmental conditions can be attributed to differences in the structure of the models. This has urged for benchmarking actions at an international level, where estimation of processoriented epistemic uncertainties is done by running several models supposed to simulate the same reality (ensemble modelling) so as to generate an expanded envelope of uncertainty (Asseng et al., 2013; Bassu et al., 2014; Li et al., 2014). We address the same issues with grassland ecosystems in Europe and Israel, with focus on permanent, semi-natural or sown grasslands under management for at least 5 years, composed of multiple plant species. Simulations of the grassland yield as well as carbon and water fluxes are inherently uncertain because they are driven by complex interactions. The present study evaluates a set of grassland models to estimate the uncertainty on yield and other outputs and explore how grassland models differ in simulations of response variables to individual climate change factors (temperature, precipitation and atmospheric $\mathrm{CO}_{2}$ concentration $\left(\left[\mathrm{CO}_{2}\right]\right)$ ).

\section{Material and methods}

In all, nine long-term grassland sites used for the modelling exercise cover a broad gradient of geographic and climatic conditions as well as a variety of management practices. In all, four of them (Laqueuille, France; Monte Bondone, Italy; Grillenburg, Germany; Oensingen, Switzerland), equipped with an eddy covariance system to determine the net ecosystem exchange (NEE) of $\mathrm{CO}_{2}$ on a daily basis, are data-rich

\footnotetext{
${ }^{\dagger}$ E-mail: gianni.bellocchi@clermont.inra.fr
}

grasslands, including gross primary production (GPP) and total ecosystem respiration (RECO) (NEE $=$ RECO $-\mathrm{GPP}$ ). At the flux-tower sites the biophysical knowledge of the grassland ecosystem is complemented with soil water content and temperature, and actual evapotranspiration measurements. Other grassland sites (Kempten, Germany; Lelystad, the Netherlands; Matta, Israel; Rothamsted, United Kingdom; Sassari, Italy) focus on forage production under a range of conditions. A total of nine models were used: AnnuGrow, ARMOSA, Biome-BGC MuSo, CARAIB, EPIC, LPJmL, PaSim, SPACSYS and STICS. Some models (AnnuGrow, EPIC and STICS) do not generate carbon fluxes. Model evaluation included uncalibrated (blind) and calibrated simulations, and responses to climate change and atmospheric factors (sensitivity runs).

\section{Results}

While the analyses are still ongoing, a few illustrative results are given.

Figure 1 shows that the boxplot of simulated yield biomass is not very different before (nine models) and after (seven models) calibration, with quite general underestimations but on average calibrated results fit better to observations. Taking the Mediterranean site of Matta (Mat) as an example, the improvement of calibration on blind tests is reflected in the values of performance indicators (with seven models, relative root mean square error from $83 \%$ to $36 \%$ ).

To study simulated responses to temperature, precipitation and $\left[\mathrm{CO}_{2}\right]$ (one factor at a time) at each site and management, six scenarios were created from the baseline weather. 
Sándor, Ma, Acutis, Barcza, Ben Touhami, Doro, Hidy, Köchy, Minet, Lellei-Kovács, Perego, Rolinski, Ruget, Seddaiu, Wu and Bellocchi
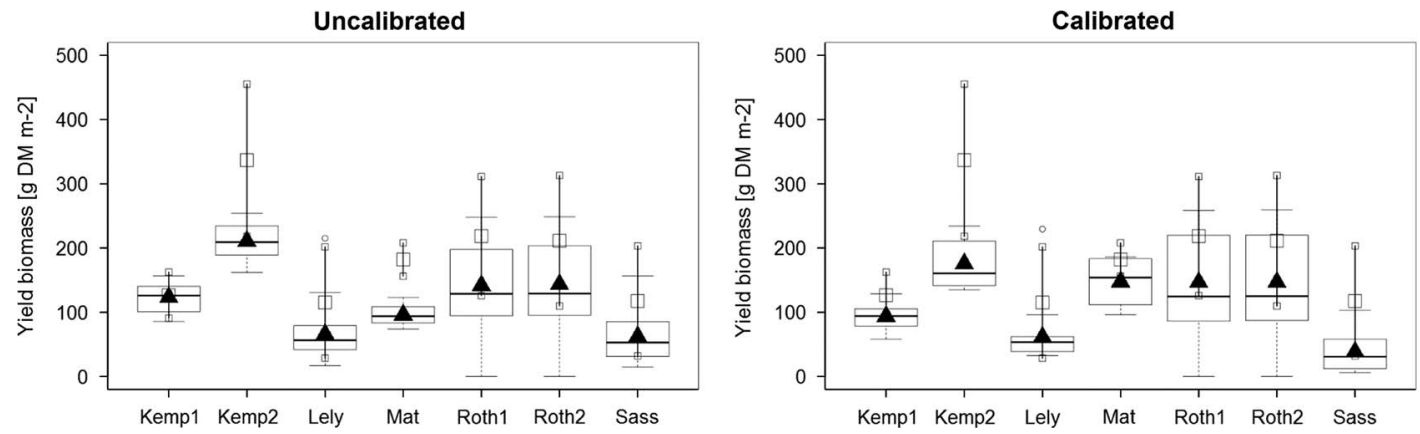

Figure 1 Observed and simulated average yearly yield biomass per cutting $\left(\mathrm{g} \mathrm{DM} \mathrm{m}^{-2}\right)$ for five locations using nine models for blind runs (left) and seven models for calibrated runs (right). Locations are: Kempten, Germany (Kemp1, cut four times per year; Kemp2, cut two times per year); Lelystad, the Netherlands (Lely); Matta, Israel (Mat); Rothamsted, United Kingdom (Roth1, $\mathrm{NH}_{4}-\mathrm{N}$ fertilization; Roth2, $\mathrm{NO}_{3}-\mathrm{N}$ fertilization); Sassari, Italy (Sass). Open squares are mean observed yields plus or minus one standard deviation. Filled triangles are the mean of simulated yields for each location. Boxes are delimiting the 25th and 75th percentiles with the median inside. Whiskers are 10th and 90th percentiles. Hollow circles indicate outliers.

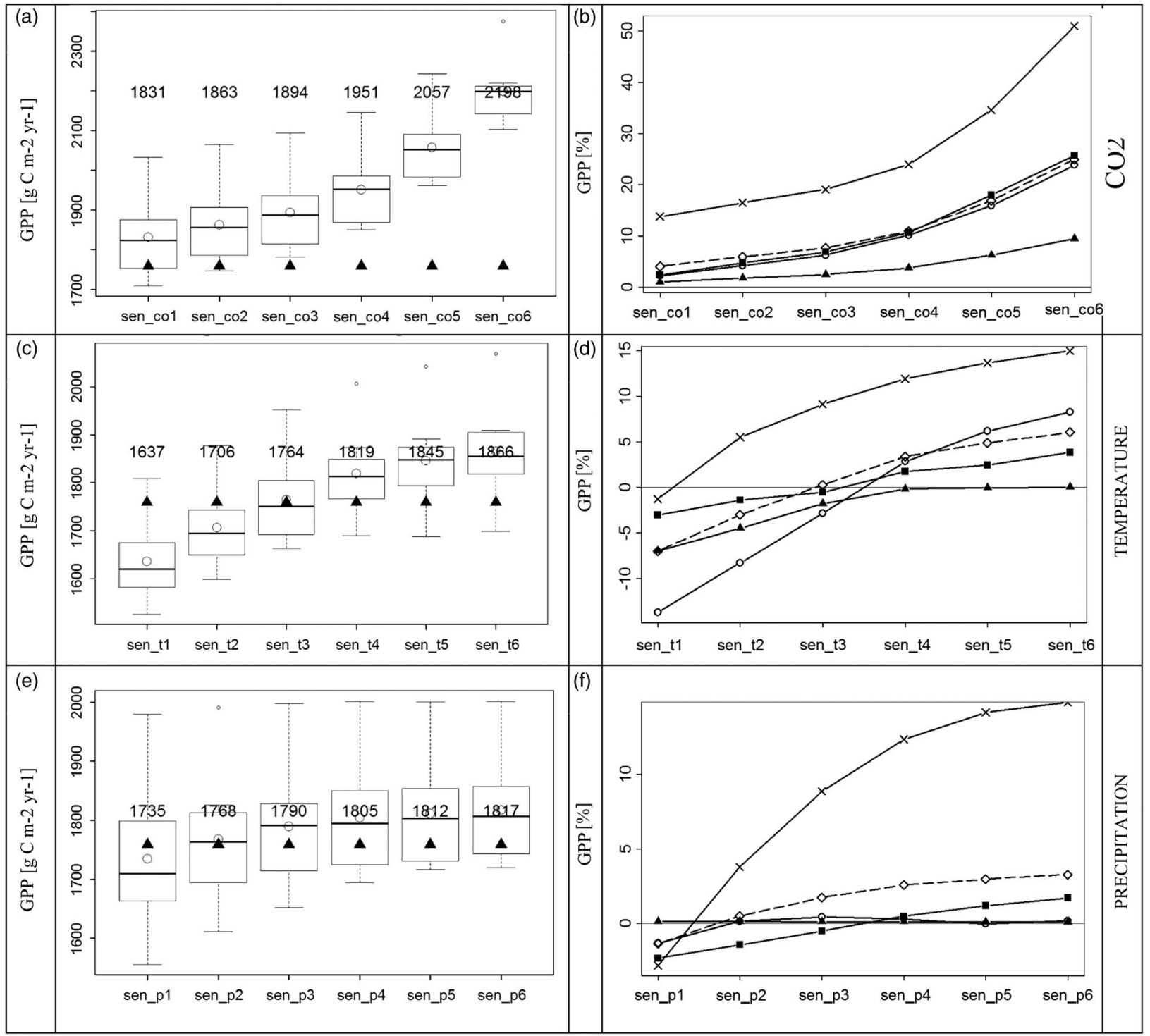

Figure 2 Simulated effects of $\left[\mathrm{CO}_{2}\right]$, temperature and precipitation changes on the yearly GPP $\left(\mathrm{g} \mathrm{C} \mathrm{m}^{-2}\right.$ year $\left.{ }^{-1}\right)$, obtained at Oensingen (Switzerland) with five calibrated models. Scenarios were generated by changing the weather baseline (2002-08): for [CO2] by $+5 \%,+10 \%,+15 \%,+25 \%,+50 \%$, $+100 \%$ on a baseline of $380 \mathrm{ppm}$ (sen_co1 to sen_co6); for hourly or daily maximum and minimum temperatures by $-25 \%,-10 \%,-5 \%,+5 \%,+10 \%$, $+25 \%$ of the standard deviation (sen_t 1 to sen_t6); for rainy hours or days, hourly or daily precipitations by $-25 \%,-10 \%,-5 \%,+5 \%,+10 \%,+25 \%$ of the standard deviation (sen p1 to sen p6). On the left, hollow circles and the values are the mean of sensitivity simulations, and filled triangles are the mean of calibrated runs (same value for each scenario). On the right, different markers indicate different models. 
Taken the example of Oensingen (Switzerland) with five models, simulated yearly changes of GPP (2002-2008 average) increases with $\left[\mathrm{CO}_{2}\right]$ at roughly exponential rate, by $\sim 25 \%$ on average with doubled $\left[\mathrm{CO}_{2}\right]$ (Figure 2a and b). The latter is in agreement with the experimental evidence (e.g., Ainsworth and Rogers, 2007). However, large differences in the response of different models to $\left[\mathrm{CO}_{2}\right]$ are visible, which suggest the need to apply an ensemble of models to capture the potential GPP changes. A common trend of the models is that yearly GPP increases with air temperature (Figure $2 \mathrm{c}$ ). On average, GPP increases by $6-7 \%$ when temperature increases by $25 \%$ but, even in this case, one model is more sensitive than others to temperature conditions and may have overestimated the effect of warming (Figure 2d). Precipitation scenarios show a lesser effect on GPP changes than temperature and $\left[\mathrm{CO}_{2}\right]$ with the exception of one model, and the average response is more complex (Figure 2e and f). At a relatively humid site like Oensingen, some reduction in precipitation can even have a positive effect on GPP owing to, for instance, less nitrogen leaching or non-saturated conditions (e.g., simulated GPP increased on average by $1 \%$ when the amount of precipitation decreased by $10 \%$ ).

\section{Conclusions}

Some calibration may be required to improve accuracy and reduce uncertainty in biomass and carbon-water cycle estimations in Europe and Israel. The results indicate that alternative models show a different sensitivity to climate change factors (which can be explained later by looking into the processes in the models) and that the application of an ensemble of models might attain better performance than a single model. In particular, the high sensitivity of simulated GPP values to $\left[\mathrm{CO}_{2}\right]$ and temperature indicates the need for model users to pay more attention on the responsiveness to these factors other than precipitation. This is important, also considering the fundamental effect of rising temperature and $\left[\mathrm{CO}_{2}\right]$ on the $\mathrm{C}$ cycling of terrestrial ecosystems (Dieleman et al., 2012).

\section{Acknowledgement}

Research performed within 'FACCE MACSUR - Modelling European Agriculture with Climate Change for Food Security, a FACCE-JPI knowledge hub'.

\section{Further information}

The LiveM International Livestock Modelling and Research Colloquium was hosted by the Basque Centre for Climate Change (BC3) at the Maritime Museum in Bilbao, Spain between 14 and 16 October 2014. LiveM is the livestock and grassland modelling theme of the EU knowledge hub Modelling European Agriculture with Climate Change for Food Security (MACSUR). The MACSUR project is a pilot knowledge hub started by FACCE-JPI in 2012. It provides an opportunity to explore the role and potential of multi-disciplinary networking structures to address complex regional and global issues. More information on MACSUR and the LiveM theme can be found at www.macsur.eu, with PDFs of slides from conference presentations available through the conference website (http:/l www.livem2014bilbao.com/).

\section{References}

Ainsworth EA and Rogers A 2007. Plant, Cell and Environment 30, 258-270.

Asseng S, Ewert F, Rosenzweig C, Jones JW, Hatfield JL, Ruane A, Boote KJ, Thorburn P, Rötter RP, Cammarano D, Brisson N, Basso B, Martre P, Aggarwal PK, Angulo C, Bertuzzi P, Biernath C, Doltra J, Gayler S, Goldberg R, Grant R, Heng L, Hooker JE, Hunt LA, Ingwersen J, Izaurralde RC, Kersebaum KC, Müller C, Naresh Kumar S, Nendel C, O'Leary G, Olesen JE, Osborne TM, Palosuo T, Priesack E, Ripoche D, Semenov MA, Shcherbak I, Steduto P, Stöckle CO, Stratonovitch P, Streck T, Supit I, Travasso M, Tao F, Waha K, Wallach D, White JW and Wolf $\mathrm{J}$ 2013. Uncertainties in simulating wheat yields under climate change. Nature Climate Change 3, 827-832.

Bassu S, Brisson N, Durand JL, Boote K, Lizaso J, Jones JW, Rosenzweig C, Ruane AC, Adam M, Baron C, Basso B, Biernath $C$, Boogaard $H$, Conijn $S$, Corbeels M, Deryng D, De Sanctis G, Gayler S, Grassini P, Hatfield J, Hoek S, Izaurralde C, Jongschaap R, Kemanian AR, Kersebaum KC, Kim SH, Kumar NS, Makowski D, Müller C, Nendel C, Priesack E, Pravia MV, Sau F, Shcherbak I, Tao F, Teixeira E, Timlin D and Waha K 2014. How do various maize crop models vary in their responses to climate change factors? Global Change Biology 20, 2301-2320.

Dieleman WIJ, Vicca S, Dijkstra FA, Hagedorn F, Hovenden MJ, Larsen KS, Morgan JA, Voder A, Beier C, Dukes JS, King J, Leuzinger S, Linder S, Luo Y, Oren R, de Angelis P, Tingey D, Hoosbeek MR and Janssens IA 2012. Simple additive effects are rare: a quantitative review of plant biomass and soil process responses to combined manipulations of $\mathrm{CO}_{2}$ and temperature. Global Change Biology 18, 2681-2693.

Li T, Hasegawa T, Yin X, Zhu Y, Boote K, Adam M, Bregaglio S, Buis S, Confalonieri R, Fumoto T, Gaydon D, Marcaida M III, Nakagawa $H$, Oriol $P$, Ruane AC, Ruget F, Singh B, Singh U, Tang L, Tao F, Wilkens P, Yoshida H, Zhang Z and Bouman B 2014. Uncertainties in predicting rice yield by current crop models under a wide range of climatic conditions. Global Change Biology. doi: $10.1111 /$ gcb.12758. 